\title{
Entrepreneurship In The Republic Of Uzbekistan: A Model For Other Emerging Nations
}

William D. Eshee, Jr. (E-mail: weshee@ cobilan.msstate.edu), Mississippi State University Ismatilla Mardanov (E-mail: itml@cobilan.msstate.edu), Mississippi State University

Pearson Liddell, Jr. (E-mail: pliddell@cobilan.msstate.edu), Mississippi State University Gloria J. Liddell (E-mail: gliddell@ cobilan.msstate.edu), Mississippi State University

\begin{abstract}
On August 31, 1991, the Republic of Uzbekistan proclaimed its independence as a free nation. As a part of the former U.S.S.R., the Uzbekistan people were required to adhere to the mandates of the Central Government in the production of manufactured goods, agricultural commodities and other goods and services. The Republic has consistently been one of the top five cotton producing countries in the world, and its economy is largely dependent on this commodity. On March 2, 1992, the Republic was admitted as a member of the United Nations and adopted its first constitution on December 8, 1992. As the Republic completes its conversion into a truly democratic nation, its leaders have taken a strong and determined stance toward fostering entrepreneurship and economic reform, privatizing business, efficiently utilizing the land base, and reversing environmental damage to the ecology of adversely affected regions. Simultaneously, government leaders took affirmative steps to maintain cotton production in order to stabilize land use policies and finance economic reform. A significant portion of governmental efforts over the last ten years have focused on encouraging free enterprise and entrepreneurship through directives which return business decision-making to entrepreneurs and business leaders. These business decisions were previously made by the Central Government which dictated production output based upon perceived needs of the former U.S.S.R. This paper will explore how the government of Uzbekistan has promoted and nurtured a spirit of entrepreneurship among its people through policies which foster free entrepreneurial thought, build viable business entities, equitably transfer public lands to private use, and reform the economy. The leaders of this emerging nation have carefully and wisely chosen the path of free enterprise which has created an ideal environment for entrepreneurship. Their efforts have succeeded in building a nation which grows more prosperous each year. The Republic of Uzbekistan is truly a nation which should serve as a model for other emerging nations of the world.
\end{abstract}

\section{The Land, The People, and The Climate}

The Republic of Uzbekistan is a Central Asian country with an interesting history and a challenging future. With a land area of 477,000 square kilometers (117,868 square miles), the country is only slightly larger than the state of California. Uzbekistan is located north of Afghanistan and shares borders with all of the Central Asian states, making it one of the only two doubly landlocked countries in the world. Thirteen different regions comprise the country, and three-fifths of the land is desert steppe separated by fertile oases along the banks of the Amu-Darya and Syr-Darya Rivers. Its capital is the city of Tashkent, and other major cities include Samarkand and Bukhara. In 2002, the population of Uzbekistan was estimated to be 26 million, making it the most highly populated Central Asian country. In addition, its annual growth rate was $1.9 \%$. The majority of the population is Uzbek, and most of the population is Muslim or Eastern Orthodox. Ninety-nine percent of the population is literate. This high literacy rate creates one of the highest human resource potentials in all of Asia. Uzbekistan's 2002 GDP was $\$ 64.5$ billion, and the annual GDP growth rate was estimated at 3\%. Per capita GDP for 2001 was $\$ 2,500$. Gross Domestic 
Product is supported mainly throughout the country. ${ }^{1}$ The country's labor force in 1998 consisted of 11.9 million people. Uzbekistan's status as the largest labor and consumer market in Central Asia is ensured due to the fact that the rate of population growth has lowered Uzbekistan's average age to only twenty-four. ${ }^{2}$

The climate of Uzbekistan can be classified as mid-latitude desert. The country has mild winters and hot summers and receives less than eight inches of rainfall per year. The country also enjoys plenty of sunshine. Daytime in the summer lasts approximately fifteen hours and no less than nine hours in the winter. This climate allows many crops to be cultivated in Uzbekistan, including cotton, tobacco, fruits, vegetables, and grain. These crops are a large source of income, as Uzbekistan is the fifth largest cotton producer in the world and the second largest cotton exporter. In addition, it is the seventh largest gold producer globally and the tenth largest natural gas producer. ${ }^{3}$ The land also supports natural resources such as petroleum, coal, uranium, silver, copper, lead, zinc, and tungsten. International investors in the mining sector find Uzbekistan very attractive because of its rich mineral resources. Textiles, automotive, food processing, and metallurgy are some of Uzbekistan's major industries. In Central Asia, Uzbekistan prides itself on being a leader in terms of economic potential. ${ }^{4}$

Over $40 \%$ of Uzbekistan's economic welfare is maintained by the agricultural and industrial sectors. In addition, the government has placed subsidies and controls on prices and production in an attempt to keep the economy from experiencing sharp declines in output and high inflation. The country has had a high account deficit because of its high growth in imports and has consequently adopted an import substitution policy. Uzbekistan's trade partners are Newly Independent States (NIS), especially Russia, Ukraine, Kazakhstan, and the other Central Asian countries. Also becoming important are the country's non-NIS partners such as the United States, Korea, Germany, Japan, and Turkey. Uzbekistan is a member of the IMF World Bank, the Asian Development Bank, the European Bank for Reconstruction and Development, and the World Intellectual Property Organization. The country has observer status with the World Trade Organization. Uzbekistan is a signatory to the Convention on Settlement of Investment Disputes Between States and Nationals of Other States, the Paris Convention on Industrial Property, the Madrid Agreement on Trademarks Protection, and the Patent Copyright Treaty. ${ }^{5}$

\section{The Road to Independence}

Uzbekistan now has a republic form of government; however, there is little power outside the executive branch. The Constitution calls for separation of powers, freedom of speech, and representative government. Currently the President has most of the power, although he seems to be moving toward more shared power. The President is the Chief of State and the Head of Government. Cabinet members are appointed by the President with the approval of the Supreme Assembly, and the President is elected by popular vote for a seven-year term. Presently, the legislative branch consists of a unicameral Supreme Assembly. In 2004 the Supreme Assembly will become bicameral. The judicial branch is comprised of the Supreme Court, with judges nominated by the President and confirmed by the Supreme Assembly. Major political parties in the country are the Fidokorlar (Workers' Party), the People's Democratic Party, the Justice Party, the Fatherland Progress Party, and the National Rebirth Party. Half of Uzbekistan's legislators do not affiliate with political parties. They are representatives of regions.

In the 16th and 17th Centuries, Russian trade grew in the region of Uzbekistan. By 1865, Russia occupied Tashkent and had taken over most of Central Asia by the 1890s. Russia promoted cotton growing in Central Asia and encouraged Russian people to settle there. In 1924, the Soviet Socialist Republic of Uzbekistan was founded. During this time, Uzbekistan was used for its cotton growing and natural resource potential. For 67 years, Uzbekistan lived under Soviet rule. Then on August 31, 1991, after the collapse of the Soviet Union, the Republic of Uzbekistan declared its independence. With this move, the country became an independent nation. ${ }^{6}$ The Supreme Council proclaimed on this day that "the territory of the Republic of Uzbekistan together with the Republic of Karakalpakstan as part of the structure shall be indivisible and inviolable. The Republic of Uzbekistan has no territorial claims to other states and exercises the supreme right to its territory and natural wealth." Under Soviet control, Uzbekistan had been one of the poorest republics. Suddenly, with its independence, it was responsible for managing its own territory and natural resources. On March 2, 1992, Uzbekistan gained membership in the United Nations. $^{7}$ 


\section{The First Steps Toward Democracy and a Free Market Economy}

Since Uzbekistan's proclamation of independence, its primary objectives have focused on forming a democratic society and a free market economy. In order to do this, the country has been entrusted to use and exploit its abundance of natural resources to raise social, economic, and living standards, and it supposedly has the power to do this without any outside help. However, even with all its natural resources, prosperity has been limited due at least partially to years of Soviet rule. Uzbekistan is moving toward a full-fledged democracy, although this change has proven to be gradual. It was the first Republic of the former Soviet Union to introduce a presidential form of government. The first President was elected in December 1991. Islam Karimov became the newly elected President for the country's new form of government. Despite the fact that, to this point, Uzbekistan has not attained its goal of implementing a full democracy, the Uzbekistan people believe that many things they could not achieve for years under Soviet rule were achieved in the first years of independence. For instance, the country now recognizes and implements the rule of law, which characterizes democratic societies. Totalitarianism is gradually being eradicated, and there is much more tolerance for diverse ideas and views. Additionally, human rights and values are now held in higher regard in Uzbekistan than they have been in the past.

Citizenship in Uzbekistan is granted much the same way as in other countries, and this right cannot be denied to anyone who is eligible. Those who can acquire citizenship include individuals living in Uzbekistan, those working by State order or studying outside the Uzbekistan borders who were born or permanently resided in Uzbekistan, and those who acquire citizenship through Uzbekistan law. The state is held accountable to its citizens and vice versa, and the rights and freedoms of the Uzbekistan citizens are protected by the state whether the citizen is residing within Uzbekistan borders or abroad. Any citizen of the Republic of Karakalpakstan is also considered a citizen of Uzbekistan.

With its independence and subsequent attempts to build democracy and a free-market economy, Uzbekistan has reached a crossroads. The Republic has the opportunity to transform itself nationally, administratively, socially, economically, spiritually, and morally. There is still much to be done in order for Uzbekistan to become a welldeveloped nation, and a strong democracy with a stable, free-market economy is the only way to ensure stable growth in the country's living standard for its people. Since its independence, Uzbekistan has made and continues to make use of other countries' experiences in gaining independence. However, the people of Uzbekistan recognize that there is not just one right solution, and concrete solutions that have worked in other countries are only applicable to the extent that other countries' conditions are similar to those in Uzbekistan. Uzbekistan realizes that it can shape its own future by understanding its past mistakes. Uzbek people also understand that decades of Soviet control that forced the population to think in certain ways cannot be eliminated easily. To succeed in genuine independence, the country must consider the population's national traits, mentality, customs, and traditions. By doing this, the country strengthens its potential economic and political independence. ${ }^{8}$ On the road to complete economic and political independence, Uzbekistan has many issues that it must face and successfully overcome. Among these issues are the creation of a free market economy through the promotion of entrepreneurship and the privatization of property. These two issues will be the focus of this paper.

\section{The National Recognition of the Importance of Entrepreneurship}

The national recognition of the importance of entrepreneurship has its foundation in the constitution of the Republic of Uzbekistan. Article 53 states:

The economy of Uzbekistan, evolving toward market relations, is based on various forms of ownership. The state shall guarantee freedom of economic activity, entrepreneurship and labor with due regard for the priority of consumers' rights, as well as equality and legal protection of all forms of ownership.

As constitutionally mandated, entrepreneurship is a guaranteed right of the Uzbekistan people. The founding fathers believed this right was so basic and important to the nation and the promotion of the economy that this right was specifically delineated and defined in its constitution. ${ }^{9}$ 
In his address to the first session of the Oliy Majlis (the Supreme Assembly) of the Republic of Uzbekistan on January 22, 2000, President Islam Karimov set forth the direction of the nation for economic reform. The emphasis of his address was on the promotion of a free market economy and entrepreneurship. The first task of government in liberalization of the economy was a reduction of controlling and regulatory functions of government by limiting its interference in the economic activity of enterprises, primarily, in the operation of private businesses. Private businesses had to be given more freedom to operate with entrepreneurs making business decisions instead of the government. More freedom had to be given to the market with the creation of a legal framework and certain economic prerequisites and guarantees for businesses. Priority should be given to developing all institutions directly linked to business, namely consulting, marketing, engineering, leasing, and insuring. The currency stabilization of the Republic was paramount in order to foster domestic and foreign investment.

Second, the government recognized the need to create a class of true business owners which the world experience has demonstrated to be required for the stability and well-being of any society. The process of further privatization should form a genuine class of owners upon which a diversified economy would develop. Upon governmental encouragement, the scale and share of private ownership of businesses would increase from year to year.

Third, a more favorable legal environment should be created to provide guarantees and economic stimuli for a comprehensive attraction of foreign investments, especially direct investments, into the economy of the country. This legal environment is necessary to ensure the active participation of foreign investment in the structural reforms of the economy, intensification of technical expertise, and modernization of the production mechanisms. It is required to encourage foreign partners and establish new joint ventures orientated toward the production of goods which are able to compete in world markets. These new entrepreneurial laws are designed to make the business climate in Uzbekistan even more attractive for foreign investors who do business in the country.

Fourth, the development of the small and medium size private business will become a priority. This priority is essential to ensure that private small and medium size businesses not only play a dominant role in the gross domestic product output, but also becomes a vital source of well-being and the growth of the income for the population as well as meaningful employment. In striving to create maximally favorable conditions for the establishment and effective functioning of privately-owned small and medium size businesses, the procedure for setting up these types of enterprises will be streamlined, and the mechanisms of consistent availability to raw material, credit resources, and equipment by entrepreneur entities will be liberalized. The importance is recognized to strengthen daily interaction between small and medium size entrepreneurs with banking and other market institutions to make them genuine partners. The same interactions should be made more accessible to larger business firms. More attention should be directed toward the creation of markets and mechanisms for the marketing, domestically and foreign, of the production of the small and medium size enterprises. The main task of government is to protect small and medium size privately owned firms from interference with its business activities by different government supervising structures which, instead of providing assistance, impede their development and interrupt their operations.

Fifth, the export potential of the nation will be developed and strengthened for the promotion of the extensive transformation of the economy into the global economic system. The volumes of exported products need to be increased in conjunction with the diversification of all exported goods in order to establish Uzbekistan in the world markets. Through a system of government sponsored stimuli and advantages, the industries of the country will be oriented toward more export activities.

Sixth, the purposeful implementation of overall structural reforms in the economy will be directed toward a more rational and efficient utilization of the vast natural, mineral and raw material and human resources of the country. A predominate place in the economy should be the accomplishment of the complete technological cycle of production which provides the final product. The processing of the mineral and agricultural raw materials should also fall into this category. Priority will be given to the development of industries based primarily on the natural and raw materials of the country. Through utilization of modern technology, the producing industries will be enabled to compete in domestic and international markets. ${ }^{10}$ 
This address clearly demonstrates that the Republic of Uzbekistan and its leaders fully understand the importance of entrepreneurship in relation to future national prosperity. The principles of economic reforms as stated by President Karimov make the main goal of economic transformation in Uzbekistan the establishment of a strong democratic state and society with a stable market economy and open foreign policy. The commitment to a market economy is based upon: (1) The logical priority of economic reforms with emphasis on privatization. The purpose of privatization is the implementation of private property and the development of entrepreneurship with a wide class of private owners. This will be accomplished by the passing of property rights from the state to companies and private persons. (2) The state will be the main reformer by determining priorities of economic development and defining the policy of large economic development transformations. (3) The sovereignty of law is affirmed with economic transformation to be implemented in accordance with applicable laws and regulations. (4) A strong social policy is established which ensures the protection of entrepreneurs by laws enacted by the sovereign during the process of transition to a market economy. (5) The state will implement economic reforms gradually over a period of time. This gradual implementation will afford maximum protection of entrepreneurs, create stability in the marketplace and economy, and allow adjustments during the transition process. ${ }^{11}$

\section{Entrepreneurship Support by the Government}

Over the past few years of the new Republic, a multitude of new decrees and laws have been passed and implemented which foster entrepreneurship and seek to disengage the government from business and business decision-making. These decrees and laws purposefully promote the entrepreneurial spirit among the Uzbekistan people and enhance the business environment for privately owned small and medium size firms. Since 1994, nine presidential decrees have been issued. In 1994 President Karimov issued a decree which provided for private property protection and the development of entrepreneurship. ${ }^{12}$ In 1995 a national business fund was created to provide financial assistance and loans for private entrepreneurship and small businesses. ${ }^{13}$ Also, in that year a national agency was established which afforded insurance protection for private entrepreneurship and small size businesses. $^{14}$ In 1996 a national chamber of manufacturers and entrepreneurs was created for the country which promoted the dissemination of business information to privately owned small to medium size enterprises. ${ }^{15}$ Additional programs seeking the stimulation of the development of small and medium size entrepreneurships were decreed in $1997 .{ }^{16}$ In 1998 regulations were placed on governmental organizations which monitored and checked on businesses. These regulations sought to eliminate governmental interference with business decisions and operations. ${ }^{17}$ In 2000 a decree was issued which dealt with the liberalization of the programs of the economic reforms relating to the political, economic and cultural spheres of Uzbekistan society. ${ }^{18}$ In 2001 two Presidential decrees were made. The first dealt with the improvement of the wholesale and stock-exchange trade. ${ }^{19}$ The second decree focused on measures designed to further stimulate the development of private entrepreneurship for small and medium size businesses. ${ }^{20}$

Since 1995, the Cabinet of Ministers of the Republic of Uzbekistan has passed sixteen resolutions which enhance the business environment for entrepreneurship. ${ }^{21}$ The following are several of the more important resolutions. In 1995 a resolution provided for the initiation and stimulation of private entrepreneurship. ${ }^{22}$ In that same year a resolution was passed which established a state supported program of development of small business and private entrepreneurship. ${ }^{23}$ In 1998 a system of simplified taxation for small enterprises was adopted. ${ }^{24}$ In 2000 measures were initiated which provided for financial support for farmers, private entrepreneurs and other small and medium size businesses. ${ }^{25}$ Also, in 2000 a resolution was passed which provided for stimulation of participation of the commercial banks of the country in the development of small and medium size entrepreneurships. ${ }^{26}$ In $2001 \mathrm{a}$ resolution dealt with the improvement of the state registration system and structured the organization of the registration of entrepreneurship entities. ${ }^{27}$ Also, in 2001 a resolution provided for insurance coverage of entrepreneurship activities. ${ }^{28}$

As a result of the enabling decrees and resolutions which have been passed, a considerable number of administrative agencies have been created which foster entrepreneurship and greatly assist those who desire to start their own businesses. A few of the more important agencies are discussed infra. The Chamber of Commodity Producers and Entrepreneurs has a number of very broad responsibilities. One primary area deals with the training 
of entrepreneurs. This is an exceptionally important function because entrepreneurs emerging from the communist system have to be taught how to think for themselves and make business decisions free from government intervention. To create an effective system of professional training for small and medium size businesses, a program of improving the training and raising the level of skill of entrepreneurs for these size businesses has been implemented. Under the umbrella of the Chamber, 23 business incubators and 207 centers for information and consulting support for entrepreneurs have been established. ${ }^{29}$ The agency represents interests and the protection of the rights of entrepreneurs, assists them in entrepreneurship activities, and aids in the establishment of favorable legislative conditions for entrepreneurship. It promotes the establishment of a proprietary class based upon the rapid development of private entrepreneurships of small and medium size businesses. It also has responsibility for assisting in the integration of the economy with world markets through establishing trade and technical assistance of Uzbek entrepreneurs with foreign entrepreneurs. ${ }^{30}$

The Private Entrepreneurship and Small Business Support Fund has the responsibility of financing investment projects with priority loans to small and medium size businesses. It provides technical assistance through consulting and information to entrepreneurs of these size businesses. Additionally, the agency provides technological support to entrepreneurs by leasing imported equipment. ${ }^{31}$

The Agency for Insurance Protection of Private Entrepreneurship and Small Business provides a number of insurance options for entrepreneurs. A few of these insurance protections include liability insurance of creditors for unpaid credit, insurance of advance payments and insurance of property, vehicles, cargo and goods. ${ }^{32}$

The Market Skills Development Center Agency provides training and retraining courses for small and medium size business personnel and infrastructure specialists. It is charged with the responsibility for developing international cooperation in education and entrepreneurship activities and rendering consulting services to entrepreneurs. Information dissemination to entrepreneurs is also provided. Additionally, the agency organizes international workshops and conferences on market economy and entrepreneurship developmental problems. ${ }^{33}$

Entrepreneurship is taught at institutions of higher learning throughout the country. The Republican Business School with its main campus in Tashkent is a state supported university with ten branches. Also, in Samarkand, the Samarkand International Business School teaches entrepreneurship. ${ }^{34}$

The emphasis on entrepreneurship promotion is demonstrated by the volume and nature of the legislative activity and the strong support of the executive branch of government. These acts and decrees which are implemented by the creation of the various administrative agencies are specifically designed to encourage and assist entrepreneurs in the creation and operation of small and medium size businesses. In its infancy, the government has correctly recognized that successful entrepreneurships in small and medium size businesses is one of the top priorities in its comprehensive plan to implement economic reform. ${ }^{35}$

\section{Entrepreneurship and Private Ownership}

Since its independence as a free nation, governmental policy has had privatization of business and the establishment of a wide class of owners and entrepreneurs as one of its principle economic reforms. The government has sought to pass property rights from the state to companies and private parties. ${ }^{36}$ The number and types of businesses authorized to be privatized has increased over the years as the nation moves toward a free economy. ${ }^{37}$ Seven presidential decrees have been issued since 2000 dealing with demonopolization and privatization. ${ }^{38}$ Railways, ${ }^{39}$ energy ${ }^{40}$ and automobiles ${ }^{41}$ were the subjects of three of these decrees. Joint-stock companies with some combination of private and public ownership presently number over $3,000 .{ }^{42}$

The Constitution of the Republic of Uzbekistan recognizes that all citizens have the right to own property. ${ }^{43}$ It also provides that private property shall be inviolable and protected by the state. ${ }^{44}$ Thus, the private ownership of personal property is authorized and protected by law. These constitutional provisions permit privatization of businesses owned by the state. Entrepreneurship is greatly enhanced by this policy. 
However, the private ownership of land is not provided for in the Constitution. Here, the Constitution mandates that land and other natural resources constitute the national wealth of the country and shall be rationally used and protected by the state. ${ }^{45}$

The issue of private land ownership was specifically addressed by President I.A. Karimov shortly after he took office in 1992.

"A key issue in the entire rural policy of the Republic is the question of land ownership. A peculiarity of our agriculture is that a considerable share of land under cultivation, and practically all land sown with industrial crops, consists of irrigated plantations maintained by a powerful state irrigation system. The density of population is high in the Republic and the current shortage of land and water, along with high rates of population growth, will result in even more acute problems in the years to come.

Turning land into a commodity will undermine the vital foundations of the population, give rise to land speculation, and deprive the farmer of confidence in the future. It is well known that the people have suffered incalculable misfortunes for centuries because of the merciless and brutal struggle for the private ownership of land. Presently we deem it necessary to preserve state ownership of land and not to permit its sale. This is related also to the irrigation systems.

The development of market relations in the countryside and the revival of a sense of proprietary interest among farmers must occur through the provision of land for perpetual use with the granting of hereditary rights. The main thing is to create an efficient economic mechanism in the village which will create the opportunities for every farmer to taste the fruits of his own labor. Only then will the farmer feel himself to be the true master of his land.

Transformations in rural areas will be carried out through democratic reforms. To achieve this we need to restore the old forms of labor organization which farmers will accept and understand. For centuries the people in the East have lived and worked in communities. The initial task of the agrarian reform is to reconstitute the cooperative forms of a production in the village. The complete centralization of agricultural production is unacceptable., ${ }^{, 6}$

Clearly, under present law and policy the ownership of land by private individuals is not permitted. A reading of President Karimov's book emphatically demonstrates that the private ownership of land in the future is not contemplated by the government. The one exception is the privately owned homestead of individuals. Here, citizens may own a specified plot of land for their individual homes with certain restrictions on alienation.

Land ownership in the broad sense under the traditional common law embodies the maximum aggregate of rights known to law and man. These rights include the rights to alienate title, commit waste (i.e., cut timber, mine minerals, etc.), mortgage, and pass the property on to heirs or others through a will or by intestate succession. For a country like the Republic of Uzbekistan, emerging from over seven decades of Communist rule, to proceed from total and complete public land ownership directly to total and complete private property ownership would probably in the words of President Karimov, "...undermine the vital foundations of the population, give rise to land speculation, and deprive the farmers of confidence in the future." ${ }^{47}$

Instead of private ownership of land, President Karimov proposes “...perpetual use with the granting of hereditary rights." ${ }^{, 48}$ The government granting perpetual use permits or patents to citizens is privatization of the land but not total privatization in the legal sense. It is believed that this proposed policy is a good, workable policy; but the question arises regarding its long-term impact on the concept of entrepreneurship.

The nature of private property and its relation to entrepreneurship date back to ancient times. Both Aristotle and St. Thomas Aquinas believed that the institution of private property was justified for three reasons, to wit: (1) people are usually better caretakers of what belongs to them personally, and do not take as good care of what belongs to society as a whole; (2) when it is clear who owns something, people are less likely to quarrel; and 
(3) when people are working for themselves and for their own private good, they work harder and are more productive than when working for the good of society. ${ }^{49}$ Having a permanent and proprietary interest in land should inspire the spirit of entrepreneurship. Perpetual use with hereditary rights does not include the right of alienation, but it permits the orderly passing of property to heirs. Knowing this, farmers and owners will have a vital interest in maintaining soil fertility. ${ }^{50}$ For the Uzbekistan people, perpetual use with hereditary rights does equate with ownership. Possessing this type of ownership should be no impediment to entrepreneurship. Business owners and farmers will be better caretakers of their land, land speculation problems will be virtually nonexistent, entrepreneurs will be more productive, and independent thinking and decision making will be the rule rather than the exception.

\section{Conclusions}

The Republic of Uzbekistan has recognized the tremendous value of individual entrepreneurship and its relationship to the accomplishment of the transition to a free economy. Entrepreneurship has been nurtured by numerous Presidential decrees and legislative fiats designed to assist small and medium size businesses. It is commendable that the government comprehends that its economic reform can be accelerated by the creation of stable and viable business firms from the lower echelons of investment. Small and medium size businesses will continue to comprise the backbone of economic reform. Innovation and high productivity will become commonplace as more and more entrepreneurs create new business enterprises. Uzbekistan has gone beyond the mere passage of entrepreneurial laws; it has effectively implemented them through adequate administrative agencies which provide financing, technical, and other assistance. The government has developed a positive attitude toward entrepreneurship which will permeate through all levels of business activity. The government has steered a course toward privatization of state-owned businesses and created joint-stock companies with ownership interests vested in both the state and private investors. This is another logical step toward a totally free economy. Although falling short of absolute ownership of land, the perpetual use of land with hereditary rights is a good solution which avoids the dangers and risks of land speculation. Perpetual use with hereditary rights conveys a sense of ownership of land and represents a giant step toward economic stabilization. This type of land ownership will encourage better care of the land, and entrepreneurs will be more productive and independent. These far-sighted efforts on part of Uzbekistan reflect the words spoken by Amir Timar (Tamelane), an Uzbekistan leader of more than six centuries ago, when he said:

"One daring, determined and vigilant person is worth a thousand indifferent and passive people."

The government of the Republic of Uzbekistan is clearly committed to the concept of entrepreneurship. Its efforts have been manifested in a wise and comprehensive government policy. Other emerging nations should look upon the Republic of Uzbekistan as a model of entrepreneurship which they should emulate.

\section{Endnotes}

1 Central Intelligence Agency. “Uzbekistan.” The World Fact Book 2002

http://www.cia.gov/cia/publications/factbook/geos/uz.html. pp. 1-9 (2002) [On-line].

2 "Country Profiles: Uzbekistan", http://www.unicef.org/programme/highlights/cee/uzbekistan/Uzbekistan.pdf. (2003) [On-line].

3 E. Akhmedov. The Republic of Uzbekistan Reference Book. http://www.cia.gov/cia/publications/factbook/geos/uz.html. pp. 61-67 (1993) [On-line].

4 Central Intelligence Agency. “Uzbekistan.” The World Fact Book, pp. 252-256 (January 1997).

5 "Republic of Uzbekistan", Background Notes on Countries of the World, pp. 1-6 (September 1998).

6 Karimov, Islam. Uzbekistan on the Threshold of the Twenty-first Century, Ch. 9, pp. 40-42 (1997).

7 Spurling, Amy: “Uzbekistan,”, New Internationalist, pp. 36-37 (October 1998).

8 Republic of Uzbekistan: Laws and Decrees, pp. 23-24 (1992).

9 Article 53, Chapter 12, "The Economic Foundation of Society", The Constitution of the Republic of Uzbekistan, adopted December 8, 1992. 
"Uzbekistan on the New Stage of Economic Reforms", Address of Islam Karimov, President of Uzbekistan at the first session of the Oliy Majlis (Parliament) of the Republic of Uzbekistan, second convocation, 22 January 2000. http://www.gov.uz/government/spc/ereforms/karimov.html. 2003 [On-line].

11 "Economic Reforms. Principles on Economic Reform", Committee for State Property Management and Entrepreneurship Support. http://www.gov.uz/government/spc/ereforms/index.html. (2003) [On-line].

12 Decree of President Islam Karimov, UP-745, January 21, 1994.

13 Id., Decree UP-1208, June 26, 1995.

14 Id., Decree UP-1207, July 26, 1995.

15 Id., Decree UP-1407, March 12, 1996.

16 Id., Decree UP-1702, January 31, 1997.

17 Id., Decree UP-2114, November 19, 1998.

18 Id., Decree UP-2612, February 6, 2000.

19 Id., Decree UP-2836, April 27, 2001.

20 Id., Decree UP-2886, June 6, 2001.

21 Resolutions of the Cabinet of Ministers of the Republic of Uzbekistan. Number 55, February 14, 1995; Number 344, August 28, 1995; Number 125, March 30, 1996; Number 159, April 15, 1996; Number 166, April 21, 1998; Number 168, April 22, 1998; Number 232, May 27, 1998; Number 65, February 2, 2000; Number 75, March 4, 2000; Number 195, May 19, 2000; Number 198, May 1, 2001; Number 263, June 22, 2001; Number 347, August 22, 2001; Number 351, August 24, 2001; Number 36, September 10, 2001; and Number 366, October 10, 2001.

22 Resolution of the Cabinet of Ministers of the Republic of Uzbekistan, Number 55, February 14, 1995.

23 Id., Resolution Number 344, August 28, 1995.

24 Id., Resolution Number 159, April 15, 1998.

25 Id., Resolution Number 75, March 4, 2000.

26 Id., Resolution Number 195, May 19, 2000.

27 Id., Resolution Number 347, August 22, 2001.

28 Id., Resolution Number 351, August 24, 2001.

29 "Protection for Entrepreneurs' Rights", http://www.gov.uz/government/spc/esupport/index7.html. (2003) [Online].

30 "Chamber of Commodity Producers and Entrepreneurs", http://www.gov.uz/government/spc/infra/22.html. (2003) [On-line].

31 "Private Entrepreneurship and Small Business Support Fund", http://www.gov.uz/government/spc/infra/23.html. (2003) [On-line].

32 "Agency for Insurance Protection of Private Entrepreneurship and Small Business", http://www.gov.uz/government/spc/infa/21.html. (2003) [On-line].

33 "Market Skills Development Center", http://www.gov.uz/government/spc/infra/24.html. (2003) [On-line].

34 "Entrepreneurship Support”, http://www.gov.uz/government/spc/esupport/index8.html. (2003) [On-line].

35 "Small and Medium-Sized Business and Individual Entrepreneurship Support in the Republic of Uzbekistan", http://www.gov.uz/government/spc/esupport/index.html. (2003) [On-line].

36 "Principles of Economic Reforms", http://www.gov.uz/government/spc/ereforms/index.html. (2003) [On-line].

37 "Resolution of the Cabinet of Ministers of the Republic of Uzbekistan", Resolution Number 119. February 9 , 2001.

38 "Demonopolization and Reforming of Strategic Branches", Decrees of President Islam Karimov. http://www.gov.uz/government/spc/legislation/drsbranches.html. (2003) [On-line].

39 Decree of President Islam Karimov, UP 2815, March 2, 2001.

$40 \quad$ Id., Decree UP 2812, February 22, 2001.

41 Id., Decree UP 2871, June 4, 2001.

42 "Management of the State-Owned Share in Joint-Stock Companies", http://www.gov.uz/government/spc/spmanagement/index.html. (2003) [On-line].

43 Article 36, Chapter 9, "Economic and Social Rights", The Constitution of the Republic of Uzbekistan, adopted December 8, 1992. 
44 Article 53, Chapter 12, "The Economic Foundation of Society", The Constitution of the Republic of Uzbekistan, adopted December 8, 1992.

45 Id. Article 55, Chapter 12.

46 Karimov, I.A. Uzbekistan: The Road of Independence and Progress, pp. 45-46 (1992).

47 Id. at p. 45.

48 Id.

49 Aristotle, Politics, bkII (The Complete Works of Aristotle, Jonathan Barnes, ed., Bollinger Series 1991); St. Thomas Aquinas, Summa Theologica, pt. II-II p. 66 (St. Thomas Aquinas, Summa Theologica, Fathers of the English Domican Province trans. 1948); both cited in Lucas vs. South Carolina Coastal Council, Takings and the Search for the Common Good, Beck-Dudley and McDonald, Academy of Legal Studies in Business, p. 158159 (1995).

50 “Human Development Report”, Uzbekistan, pp. 35-36 (1996).

51 Timar, Amir (Tamelane), quoted in "Entrepreneurship Support", http://www.gov.uz/government/spc/esupport/index.html. (2003) [On-line]. 